Citation: G. V. Volkova, O. A. Kudinova, I. P. Matveeva (2021) Virulence and diversity of Puccinia striiformis in South Russia. Phytopathologia Mediterranea 60(1): 119-127. doi: 10.36253/ phyto-12396

Accepted: February 11, 2021

Published: May 15, 2021

Copyright: () 2021 G. V. Volkova, O. A. Kudinova, I. P. Matveeva. This is an open access, peer-reviewed article published by Firenze University Press (http://www.fupress.com/pm) and distributed under the terms of the Creative Commons Attribution License, which permits unrestricted use, distribution, and reproduction in any medium, provided the original author and source are credited.

Data Availability Statement: All relevant data are within the paper and its Supporting Information files.

Competing Interests: The Author(s) declare(s) no conflict of interest.

Editor: Diego Rubiales, Institute for Sustainable Agriculture, (CSIC), Cordoba, Spain.

\section{Research Papers \\ Virulence and diversity of Puccinia striiformis in South Russia}

\author{
Galina V. VOlKOVA, Olga A. KUDINOVA*, Irina P. MATVEEVA \\ FSBI Federal State Budgetary Scienti!c Institution, All-Russian Scienti!c Center of Biologi- \\ cal Plant Protection, 350039 Krasnodar, Russia \\ *Corresponding author. E-mail: alosa@list.ru
}

Summary. Puccinia striiformis causes wheat yield losses in all countries where wheat is cultivated. Virulence and diversity of the P. striiformis were assessed in 2013-2018 in South Russia, and this showed that the North Caucasian population of the pathogen was diverse. One hundred and eighty two virulence phenotypes were identified in 186 P. striiformis isolates. Among isolates collected in 2014, 2015, and 2018, all phenotypes were unique. In the 2013 and 2017 populations, phenotypes with few (one to eight) virulence alleles prevailed. In the 2014,2015 , and 2018 populations, most of the phenotypes contained greater numbers (nine to 19) of virulence alleles. Over the 5 years of research, the pathogen population lacked isolates virulent to the host $\mathrm{Yr}$ resistance genes 3, 5, 26, and Sp. Single (from 1 to 5\%) occurrences of isolates virulent to host lines with Yr genes $3 a, 17,24,3 b+4 a+H 46$, and $3 c+$ Min were identified. Differences in frequencies of virulence alleles between years in the $P$. striiformis populations (Ney indices, $\mathrm{N})$ were generally non-significant $(\mathrm{N}=0.11$ to 0.23$)$, with the exception of the populations in 2013 and $2017(\mathrm{~N}=0.37)$. The minimum $\mathrm{N}$ values was found for the populations of 2015 and $2018(\mathrm{~N}=0.10)$. Over the five years of this study, the dynamics of the virulence of the population and jumps in the frequency of isolates with respect to many Yr genes were identified. This feature of the P. striiformis populations in South Russia, combined with high phenotypic diversity, indicates the ability for rapid race formation and morphogenesis in response to changes in biotic and abiotic factors.

Keywords. Yellow rust, virulence, effective resistance genes, pathogen population.

\title{
INTRODUCTION
}

The yellow rust pathogen (Puccinia striiformis West. f. sp. tritici Erikss. et Henn.) causes wheat yield losses in all countries where this crop is grown (Singh et al., 2004; Bux et al., 2011; Hovmøller et al., 2017). This pathogen can also infect barley, rye and more than 50 species of herbs (Waqar et al., 2018). Puccinia striiformis has rapid coupled evolution with the formation of new virulent races that can infect previously resistant wheat varieties (Wellings and McIntosh, 1990; Hovmøller and Justesen, 2007). Recent spread of the pathogen has been limited to regions with temperate climates. Since 2010, new races of $P$. striiformis have caused serious yellow rust epidemics in India, Iran, Pakistan (Afshari, 2008; MacKenzie, 2011), the United States of 
America and Canada (Wan and Chen, 2014), Australia (Wellings and Kandel, 2004), Ethiopia (Gebreslasie et al., 2020), Egypt (Ashmawy et al., 2019; Shahin et al., 2020) and other countries.

In Russia, until the end of the 1960s, yellow rust had no economic significance, although the disease was periodically recorded (Morozova, 1974). Since 1990, in the south of Russia, there has been a steady expansion of the area affected by this disease (Chuprina et al., 1999; Shumilov and Volkova, 2013). The main regions of South Russia are Krasnodar, Stavropol and Rostov. These regions are leading in the production of winter cereal crops ( $49 \%$ of the total Russian production), and are characterized by favourable weather conditions for the development of phytopathogens, including P. striiformis. Foci of infection appear in epiphytotic years due to migration of the pathogen from the Transcaucasus, where a maternal $P$. striiformis population with high variability is formed, to foothills in Dagestan, Ossetia, Ingushetia, Kabardino-Balkaria, adjacent steppe regions of the Stavropol and Krasnodar Regions (Chuprina et al., 1999). The infected area in 1995 to 1997 in some regions of southern Russia was 56 to 63\% (Berdysh, 2002). In 1997, in Krasnodar region, the infected area varied between 30 and 90\% (Dobryanskaya et al., 1999). In 2001, an epiphytotic of yellow rust occurred (Berdysh, 2002). In 2004 and 2008, the development of yellow rust, especially in the southern foothill zone of the region, reached 20 to $40 \%$ with wheat yield losses of 10 to 15\% (Sanin and Nazarova, 2010). The proportion of $P$. striiformis in the pathocomplex during 2001 to 2008 averaged $8 \%$ and varied from 5 to $22 \%$. In 2004 , moderate yellow rust development was noted, while in 2001 to 2003 and 2005 to 2007, low level of this disease occurred. In 2009-2011, the development of yellow rust ranged from 0.3 to $6.1 \%$. In 2012, the pathogen was not detected in the region, which is most likely due to the low temperatures that occurred in winter. In 2013 to 2017, development and spread of yellow rust remained at the level of previous years and fluctuated from 0.2 to 3.5\%. In 2018, the development of the disease was less than 2\% (Volkova et al., 2018; Matveeva, Volkova, 2019).

Traditionally, in large areas of cultivation, yellow rust is controlled by the use of effective fungicides. However, with the trend towards "greening" of agricultural production, biosafety methods for protecting wheat from yellow rust are becoming increasingly important, with method being the use of disease-resistant wheat varieties (Aktar-Uz-Zaman et al., 2017). To effectively use their potential, a substantiated strategy for host variety distribution in agrolandscape niches is necessary, but this cannot be achieved without knowledge of virulence of phytopathogen population (Wellings, 2011). Thus, monitoring the virulence dynamics of the $P$. striiformis population is an important tool for disease management (Chen, 2005; Ali et al., 2017).

The aim of the present study was to assess diversity and virulence dynamics of $P$. striiformis populations in southern Russia during 2013 to 2018.

\section{MATERIALS AND METHODS}

\section{Route surveys and sample collection}

The collection of yellow rust material was carried out in late May to early June of each year, from wheat crops and plant breeding sites in the main grain-producing regions of southern Russia, including Krasnodar, Stavropol and Rostov. Leaves with urediniopustules were wrapped in filter paper and labelled with dates and localities of collection, and were stored during the survey periods in a portable refrigerator. When storing samples in the laboratory, collected leaves were dried and then placed in a refrigerator at $2-4^{\circ} \mathrm{C}$.

\section{Weather conditions of growing seasons}

In 2013, spring was prolonged with frequent rains, which favourably affected development of yellow rust. In 2014, positive deviations of air temperature prevailed in the early spring period. Heavy rains fell in the second half of March, which contributed to the development of yellow rust on crops. The spring of 2015 was early, unstable, and protracted, with intense frosts in late March to early April, and there were intense frosts (-1 to $-5^{\circ} \mathrm{C}$ ). The cold weather in April reduced growth and development of diseases, but these conditions did not affect yellow rust development. In spring of 2017, frequent rains and low temperatures favoured yellow rust development. 2018 was an unfavourable year for development of yellow rust. The combination of high temperatures and low soil moisture in spring limited development of the pathogen.

\section{Multiplication of Puccinia striiformis isolates}

Multiplication of infectious material for isolation of $P$. striiformis monopustule isolates was carried out on the highly susceptible wheat variety Kaw (United States of America). This was carried out in a greenhouse, using optimal temperature $\left(15\right.$ to $18^{\circ} \mathrm{C}$ ), humidity (60 to $80 \%$ ) and lighting (12,000 to 15,000 lux) for development of 
the pathogen (Anpilogova and Volkova, 2000). Wheat plants were grown in $0.5 \mathrm{~L}$ capacity pots, five to eight plants in each pot, until their second leaves appeared (germination phase). The wax bloom was then removed from the plants by lightly rubbing the leaves with slightly moistened fingers, and suspensions of urediniospores of the respective populations were applied at low concentration. Water was then applied to the plants with a pump sprayer and the plants were placed in a humid chamber for 18 to $20 \mathrm{~h}$ at 13 to $16^{\circ} \mathrm{C}$, after which they were transferred to isolated boxes in a greenhouse. After 13 to $14 \mathrm{~d}$, when first signs of disease appeared, only one plant with a single chlorotic spot was left in each pot. This plant was covered with an insulator $10 \mathrm{~cm}$ in diameter, with a double layer of gauze fixed on top.

Multiplication of $P$. striiformis isolates was carried out on the same variety using the methods described above. Urediniospores were collected into test tubes, which were identified isolate identifications and agroclimatic zones.

\section{Virulence analysis of Puccinia striiformis isolates}

To study the virulence of the pathogen population, standard sets of host differentials and lines, carrying 41 resistance genes (Table 1), were used. Perforated pots each containing $25 \mathrm{~mL}$ of sand were placed on trays, and were irrigated with Knop's nutrient solution (stock solution: $100 \mathrm{~g}$ calcium nitrate, $25 \mathrm{~g}$ potassium phosphate, 25 $\mathrm{g}$ of magnesium sulphate, $12.5 \mathrm{~g}$ potassium chloride, 0.1 $\mathrm{g}$ of ferric chloride, in $1 \mathrm{~L}$ water). For irrigation, $100 \mathrm{~mL}$ of the stock solution was diluted in $10 \mathrm{~L}$ of water and the trays were filled with the nutrient mixture (Smirnova and Alekseeva, 1988).

Sprouted seeds of differentials and near isogenic lines were sown into pots, at five seed per pot. In the 1-2 true leaf phase, When resulting plants were at the one to two leaf stage, they were inoculated with each of $P$. striiformis isolates. A tray with each set of varieties and lines was designated by the isolate number with which the plants were infected. At 14 to $18 \mathrm{~d}$ after inoculation, when the type of reaction was well pronounced, the reaction was assessed. The type of reaction was determined using the Gassner and Streib scale (Roelfs et al., 1992). Varieties and lines with reaction type i, 0, 1 and 2 were considered resistant to the isolate, and type 3.4 as susceptible. a virulence formula was then determined, where the effective resistance genes of each host plant were indicated in the numerator, and the ineffective genes were indicated in the denominator (Green, 1965).
Table 1. Sets of host plant differentials, near isogenic lines of variety Avocet and additional varieties with known resistance genes for characterizing Puccinia striiformis virulence.

\begin{tabular}{|c|c|c|c|}
\hline $\begin{array}{l}\text { Varieties and } \\
\text { lines }\end{array}$ & Yr Gene(s) & Varieties and lines & Yr Gene(s) \\
\hline International set & & Fielder & $6+20$ \\
\hline Chinese $166^{*}$ & 1 & Tyee & Tye \\
\hline $\mathrm{Lee}^{\star}$ & $7+22+23$ & Tres & $\operatorname{Tr} 1+\operatorname{Tr} 2$ \\
\hline Heines Kolben & $2+6$ & Hyak & 17 \\
\hline Vilmorin 23 & $3 a+4 a+V 23$ & Express & Exp1+Exp2 \\
\hline Moro $^{*}$ & 10+Mor & \multirow{2}{*}{\multicolumn{2}{|c|}{$\begin{array}{l}\text { Australian set on the base of } \\
\text { variety Avocet }\end{array}$}} \\
\hline Strubes Dickkopf & $\mathrm{SD}+25$ & & \\
\hline Suwon $92 \times$ Omar & $\mathrm{SU}$ & Yr1 / 6 Avocet S & 1 \\
\hline Clement* & $2+9+$ Cle & Yr5 / 6 Avocet $S^{*}$ & 5 \\
\hline T. spelta album & 5 & Yr6 / 6 Avocet S & 6 \\
\hline European set & & Yr7 / 6 Avocet S & 7 \\
\hline Hybrid 46 & $3 b+4 b+\mathrm{H} 46$ & Yr8 / 6 Avocet $S^{*}$ & 8 \\
\hline Reichersberg 42 & $7+25$ & Yr9 / 6 Avocet $S^{*}$ & 9 \\
\hline Heines Peko & $2+6+25$ & Yr10 / 6 Avocet S & 10 \\
\hline Nord Desprez & $3 a+4 a+N D$ & Yr15 / 6 Avocet S & 15 \\
\hline Compair* & $8+19$ & Yr17 / 6 Avocet S & 17 \\
\hline Carstens V & $25+32$ & Yr24 / 6 Avocet S & 24 \\
\hline Spaldings prolific & $\mathrm{Sp}+25$ & Yr26 / 6 Avocet S & 26 \\
\hline Heines VII ${ }^{\star}$ & $2+\mathrm{HVII}$ & Yr27 / 6 Avocet S & 27 \\
\hline American set & & Yr32 / 6 Avocet S & 32 \\
\hline Lemhi & 21 & YrSp / 6 Avocet S & $\mathrm{Sp}$ \\
\hline Paha & $\mathrm{Pa} 1+\mathrm{Pa} 2+\mathrm{Pa} 3$ & Avocet Resistans & $\mathrm{A}$ \\
\hline Druchamp & $3 a+$ Dru+Dru2 & Jupateco $73 \mathrm{R}$ & 18 \\
\hline Produra & $\operatorname{Pr} 1+\operatorname{Pr} 2$ & additional varieties & \\
\hline Yamhill & $2+3 a+Y a m$ & Minister & $3 c+$ Min \\
\hline Stephens & $3 a+$ Ste + Ste 2 & Vuka & $4 b$ \\
\hline
\end{tabular}

* Host varieties and lines also included in the American set of differentiator varieties.

\section{Statistical analyses of results}

The level of diversity of $P$. striiformis phenotypes was assessed using the Shannon index (Hw) according to the formula (Kolmer et al., 2003):

$\mathrm{H}_{\mathrm{w}}=-\sum p i \ln (p i) / \ln (n)$

where $p i$ is the frequency of $i$-th phenotype in the population, and $n$ is = the total number of isolates of the population.

The diversity of the $P$. striiformis population The frequencies of virulence genes was described using the Ney diversity index $\left(\mathrm{H}_{\mathrm{s}}\right)$ (Kosman and Leonard, 2007):

$$
\mathrm{H}_{\mathrm{s}}(P)=\Sigma\left[1-q_{i}^{2}-\left(1-q_{\mathrm{i}}\right)^{2}\right] / k, 1 \leq i \leq k,
$$


where $q_{i}$ is the frequency of $\mathrm{i}$-th gene in this population, and $\mathrm{k}=$ number of genes.

The differences of frequencies of virulence genes between the $P$. striiformis populations were assessed using Ney's genetic distance (Kosman, 1996):

$\mathrm{N}=\sum \sum \mathrm{x}_{\mathrm{ij}} \mathrm{y}_{\mathrm{ij}} / \sqrt{ } \sum \sum \mathrm{x}_{\mathrm{ij}}^{2} \sum \sum \mathrm{y}_{\mathrm{ij}}^{2}$,

where $\mathrm{x}_{\mathrm{ij}}$ and $\mathrm{y}_{\mathrm{ij}}$ indicate frequencies of $\mathrm{i}$-th allele, in the $\mathrm{j}$-th year in compared populations.

\section{RESULTS}

Virulence of the wheat yellow rust pathogen population

For the period from 2013 to 2018, virulence of 186 isolates of $P$. striiformis was described (Table 2). Of 41 host lines with resistance genes, 38 showed different responses to $P$. striiformis infection.

Over the 5 years of study, the pathogen population lacked isolates virulent to the $Y r$ resistance genes 3, 5, 26, or Sp. Single (from 1 to 5\%) occurrences were observed of isolates virulent to lines with the $\mathrm{Yr}$ genes $3 a, 17,24,3 b+4 a+H 46$, or $3 c+$ Min. In 2009, 1010 and 2011, isolates affecting varieties with Yr17 occurred with a frequency of $30 \%$, while isolates virulent to the $\operatorname{Yr} 3 c+$ Min gene were absent in the population (Shumilov et al., 2015). The frequency of $P$. striiformis isolates virulent to the lines with the $Y r$ genes $4+12,6,7+25,2+H V I I$, $32,2+9$, or $S D$ remained at an average level and varying from 6 to $20 \%$.

The frequency of isolates on host lines with the Yr genes 1, 2, 4b, 21, SU, $2+6,7+22+23$, or $8+19$ remained stably high (30-80\%). On differentiator varieties with the $Y r$ genes $39+A l p$ and $D a 1+D a 2$ the frequency of isolates was high in all years of study, except 2017. On varieties and lines with $Y r$ genes $7,9,10,15$, $18,25,10+$ Mor , $3 a+4 a+V 23$, or $25+32$, high polymorphism of the pathogen reaction types was observed. There was also a decrease in the frequency of isolates for the line with the $Y r 8$ gene, and an increase for the line with the $Y r 3 a+4 a+N D$ genes.

Diversity of Puccinia striiformis populations by virulence phenotypes

The study of the phenotype composition of the North Caucasian population of the wheat yellow rust pathogen revealed significant diversity; 182 virulence phenotypes were identified from $186 P$. strifformis isolates. Among the isolates from the populations of 2014,
Table 2. Frequency (\%) of isolates with virulence alleles in the North Caucasian population of Puccinia striiformis $f$. tritici during 2013 to 2018.

\begin{tabular}{|c|c|c|c|c|c|}
\hline \multirow{2}{*}{$\begin{array}{l}Y r \text { genes of } \\
\text { virulence }\end{array}$} & \multicolumn{5}{|c|}{ Yr gene frequency (\%) and Years of assessment } \\
\hline & 2013 & 2014 & 2015 & 2017 & 2018 \\
\hline 1 & 30.6 & 87.8 & 78.3 & 40 & 52.7 \\
\hline 2 & 50.0 & 69.4 & 65.7 & 30 & 45.1 \\
\hline $3 a$ & 0.0 & 2.0 & 0.0 & 5 & 1.6 \\
\hline $4+12$ & 8.3 & 6.1 & 7.0 & 20 & 5.8 \\
\hline $4 \mathrm{~b}$ & 25.0 & 81.6 & 71.6 & 55 & 42,4 \\
\hline 6 & 0.0 & 6.1 & 8.2 & 0 & 2.8 \\
\hline 7 & 11.1 & 8.2 & 10.4 & 40 & 0.0 \\
\hline 8 & 19.4 & 10.2 & 11.8 & 5 & 0.0 \\
\hline 9 & 0.0 & 67.3 & 12.5 & 45 & 22.2 \\
\hline 10 & 16.7 & 79.6 & 18.1 & 10 & 5.1 \\
\hline 15 & 11.1 & 81.6 & 37.4 & 30 & 13.9 \\
\hline 17 & 0.0 & 4.1 & 1.2 & 0 & 4.8 \\
\hline 18 & 8.3 & 51.0 & 10.6 & 40 & 62.7 \\
\hline 21 & 58.3 & 79.6 & 44.8 & 30 & 64.3 \\
\hline 24 & 0.0 & 4.1 & 0.0 & 0 & 2.8 \\
\hline 25 & 19.4 & 85.7 & 20.2 & 30 & 18.6 \\
\hline 27 & 11.1 & 2.0 & 2.1 & 0 & 0.0 \\
\hline 29 & 30.6 & 69.4 & 56.7 & 15 & 49.1 \\
\hline 32 & 0.0 & 12.2 & 10.1 & 5 & 17.2 \\
\hline $2+9$ & 0.0 & 12.2 & 10.8 & 20 & 10.8 \\
\hline SU & 22.2 & 57.1 & 48.3 & 15 & 44.4 \\
\hline SD & 5.6 & 8.2 & 5.2 & 5 & 7.2 \\
\hline $10+$ Mor & 5.6 & 46.9 & 10.1 & 20 & 5.6 \\
\hline $3 a+4 a+V 23$ & 16.7 & 51.0 & 34.1 & 35 & 28.4 \\
\hline $2+6$ & 48.9 & 73.5 & 51.0 & 40 & 46.1 \\
\hline $7+22+23$ & 41.7 & 75.5 & 59.7 & 45 & 52.5 \\
\hline 2+HVII & 11.1 & 6.1 & 10.9 & 20 & 19.4 \\
\hline $25+32$ & 0.0 & 65.3 & 1.2 & 15 & 14.8 \\
\hline $8+19$ & 55.6 & 65.3 & 31.8 & 40 & 41.4 \\
\hline $3 a+4 a+N D$ & 19.4 & 10.2 & 16.1 & 20 & 35.6 \\
\hline $2+6+25$ & 8.3 & 30.0 & 24.6 & 35 & 16.7 \\
\hline $7+25$ & 19.4 & 8.2 & 6.1 & 20 & 10.4 \\
\hline $3 b+4 a+H 46$ & 0.0 & 2.0 & 0.0 & 5 & 3.6 \\
\hline A & 19.4 & 63.3 & 54.4 & 35 & 72.2 \\
\hline $\mathrm{Da} 1+\mathrm{Da} 2$ & 13.9 & 32.7 & 27.5 & 0.0 & 18.4 \\
\hline 39+Alp & 41.7 & 57.1 & 49.8 & 0.0 & 51.3 \\
\hline $3,5,26, \mathrm{Sp}$ & 0.0 & 0.0 & 0.0 & 0.0 & 0.0 \\
\hline $3 c+$ Min & 2.8 & 0.0 & 0.0 & 0.0 & 1.6 \\
\hline Number of isolates & 36 & 49 & 45 & 20 & 36 \\
\hline
\end{tabular}

2015, and 2018, all the phenotypes were unique. In the 2013 pathogen population, four phenotypes occurred twice. Diversity of the populations (frequencies of virulence alleles) remained at a moderate average level (Table 3). 
Table 3. Ney and Shannon indices for Puccinia striiformis populations in South Russia, during 2013 to 2018.

\begin{tabular}{ccccc}
\hline Year & $\begin{array}{c}\text { Number of } P . \\
\text { striiformis isolates }\end{array}$ & $\begin{array}{c}\text { Number of } \\
\text { phenotypes }\end{array}$ & $\begin{array}{c}\text { Ney index } \\
(\mathrm{Hs})\end{array}$ & $\begin{array}{c}\text { Shannon } \\
\text { index (Sh) }\end{array}$ \\
\hline 2013 & 36 & 32 & 0.21 & 0.96 \\
2014 & 49 & 49 & 0.27 & 1.0 \\
2015 & 45 & 45 & 0.26 & 1.0 \\
2017 & 20 & 20 & 0.27 & 1.0 \\
2018 & 36 & 36 & 0.27 & 1.0 \\
\hline
\end{tabular}

Differences between Puccinia striiformis populations in 2013 to 2018 by frequencies of virulence alleles

The populations of P. striiformis in 2013 to 2018 was compared for the number of virulent alleles (Figure 1). The population of the pathogen in 2013 was characterized by reduced virulence, and phenotypes with small numbers (1-8) of virulence alleles. In contrast, the 2014 population was characterized by a predominance of highly virulent isolates with medium and high levels of virulence alleles.

The 2015 P. striiformis population was also dominated by isolates with medium numbers of virulence alleles. In the 2017 population of the pathogen, isolates with short virulence formulae prevailed, although isolates with a medium and high content of virulent alleles totalled 50\%. The 2018 population was characterized by an approximately equal ratio of isolates containing medium and large numbers of virulence alleles. Thus, from year to year, the virulence of the populations varies greatly, which indicated the pathogen ability for rapid

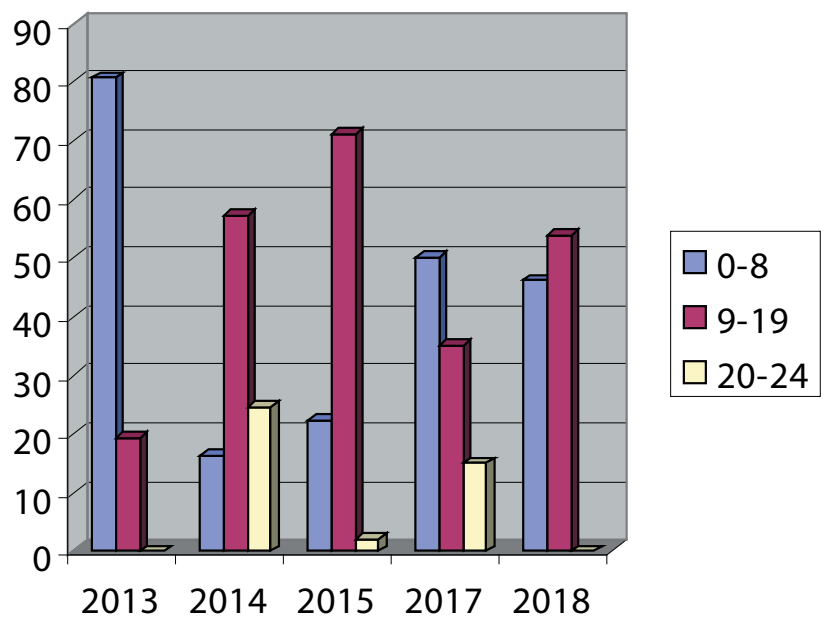

Figure 1. Frequency of Puccinia striiformis phenotypes with different numbers of virulence alleles in South Russia during 2013 to 2018.
Table 4. Ney indices for Puccinia striiformis populations in South Russia during 2013 to 2018 , as indicated by the frequencies of virulence alleles.

\begin{tabular}{lcccc}
\hline $\begin{array}{l}\text { Compared } \\
\text { pairs }\end{array}$ & \multicolumn{3}{l}{ Year of assessments of Puccinia striiformis } & populations \\
\cline { 2 - 5 } & 2013 & 2014 & 2017 & 2018 \\
\hline 2013 & & 0.23 & 0.37 & 0.17 \\
2014 & & & 0.15 & 0.14 \\
2015 & 0.18 & 0.11 & 0.21 & 0.10 \\
2017 & & & & 0.20 \\
\hline
\end{tabular}

race formation in response to changes in biotic and abiotic factors.

The differences in frequencies of virulence alleles in the P. strifformis populations between years, as shown by Ney indices were generally insignificant (Table 4), with the exception of populations in 2013 and 2017 (N $=0.37$.

The minimum Ney index value was found between Puccinia striiformis populations in 2015 and 2018 ( $\mathrm{N}=$ $0.10)$.

\section{DISCUSSION}

The established diversity of the P. striiformis population in southern Russia in terms of virulence phenotypes, noted earlier in previous studies (Shumilov et al., 2015; Volkova, 2020), has been primarily associated with the large number of cultivated winter wheat varieties. In the Krasnodar region, about 98 varieties are grown, in the Rostov region, 125 varieties, and in the Stavropol region, 140 winter wheat varieties are used.

The effective $Y r$ genes 3, 5, 26, and $S p$ partially retained their efficiency shown in previous years. For host lines with resistance genes $\operatorname{Yr} 5$ and $\mathrm{YrSp}$, this tendency has continued since 2009 (Shumilov, 2013), although the moderate frequency of isolates virulent to Yr26 in 2009 to 2011 was about 6\%. In populations of the $P$. striiformis in other continents, the effectiveness of a number of resistance genes has been similar. For example, in western Canada for many years (1984 to 2013) the host lines with $Y r$ genes $1,5,15$, and $S P$ were not affected by the pathogen, and starting in 2010, isolates virulent to $\mathrm{Yr}$ genes 24 and 26 started to occur (Brar et al., 2016; 2018). In the United States of America, Yr genes 5, and 15 have been effective since 1960 (Liu et al., 2017). In contrast, in Kazakhstan, Yr5, Yr9, Yr26, and $Y r 27$ are considered to be effective genes (Rsaliev, 2008), while in South Russia Yr9 has lost its effectiveness and the frequency of $P$. striiformis isolates infecting 
Yr27 was from 2 to $11 \%$ (Table 2). Isolates from Pakistan and the United States of America were avirulent to lines with genes Yr5, Yr15, and YrSP (Bux et al., 2012). The Yr26 gene, which was effective in South Russia, is gradually losing effectiveness in regions of China, which are especially prone to yellow rust. This is probably due to active use of this gene in wheat breeding in these regions (Han et al., 2015). In 2015, P. striiformis isolates virulent to Yr26 were also found in Mexico (Huerta-Espino and Singh, 2017). In Europe, western and central Asia and Africa, this gene has retained effectiveness (Howmoller et al., 2020). The appearance and spread of new races in Europe and North Africa, which are annually recorded in new territories, causes concern. For example, the race "Warrior" (PstS7), discovered in 2011 in the United Kingdom (virulence profile $Y r 1,2,3,4,6,7,9,17,25,32$, $S p, A v S$, and $A m b$ ), and introduced into the European population of the pathogen, caused increased yield losses in many varieties (Rahmatov, 2016). In 2016, a virulent race was found in Ukraine and Azerbaijan (Hovmøller et al., 2018). In Russia, Yr3 and YrSp still retain their effectiveness, but the appearance of virulent races in neighbouring regions dictates the need for careful monitoring of the virulence of $P$. striiformis populations.

Thus, the Yr5, Yr15, and Yr26 genes have remained effective in different regions of the world for many years. This is probably due to their origins. The $\operatorname{Yr} 5$ gene was obtained from the wild species Triticum spelta album, the $\mathrm{Yr} 15$ gene from Triticum dicoccoides, (GerechterAmitai et al. 1989), and the Yr26 gene was transferred from durum wheat to soft wheat via amphiploid with Aegilops tauschii (McIntosh and Lagudah, 2000). These three genes belong to the group of so-called ASR genes, which are distinguished by their efficacy at all stages of plant growth (Wang and Chen, 2017). For the P. striiformis population in southern Russia, the frequency of isolates virulent to lines with $\operatorname{Yr} 15$ genes varied from 11 to $82 \%$.

Dynamics of the frequency of $P$. striiformis isolates to some differential varieties and lines with $\mathrm{Yr}$ genes can be traced, starting from 2009 (Figure 2 and Figure 3) (Shumilov, 2013).In 2014, there was a sharp increase in the frequency of pathogen isolates virulent to varieties and lines with genes Yr25 + 32 and Yr10 + Mor. In subsequent years, the frequencies decrease. A similar surge was observed for most of the other $\mathrm{Yr}$ genes, including 1, $2,4 b, 9,10,15,21,25,29, S U, 3 a+4 a+V 23,2+6$, and $7+22+23$. In general, however, there were no significant differences between the 2014 population and other populations. This indicates that the pathogen populations were clonal, and the variability was probably due to weather conditions or rotation of varieties, and not from pathogen introductions from outside the region.

Comparing the frequencies of virulence alleles with similar results in previous years indicates that the resistance of some effective genes has gradually been lost (see Figures 2, and 3). For example, the frequency of isolates virulent to testers with the genes $\operatorname{Yr} 3 a+4 a+N D$ and Yr2 + 9 in 2009 to 2011 did not exceed 5\%, while from 2013 to 2015 this was greater ranging from 6 to $19 \%$.

A specific feature of the North Caucasian P. striiformis populations has been the low or moderate frequency of occurrence of isolates virulent to a number of differential lines based on the wheat variety Avocet, as compared to pathogen populations in Canada and the United States of America. For example, in the pathogen population in Canada in 2012, there was high frequency of pathogen isolates (70 to 100\%) with virulence to YrA, Yr2, Yr6, Yr7, Yr8, Yr9, Yr17, Yr26, Yr27, Yr31 and Yr32 (Kumar et al., 2012). In the South Russian population, the frequency of isolates virulent to most of these lines ranged from 6 to $17 \%$. Therefore, for a complete

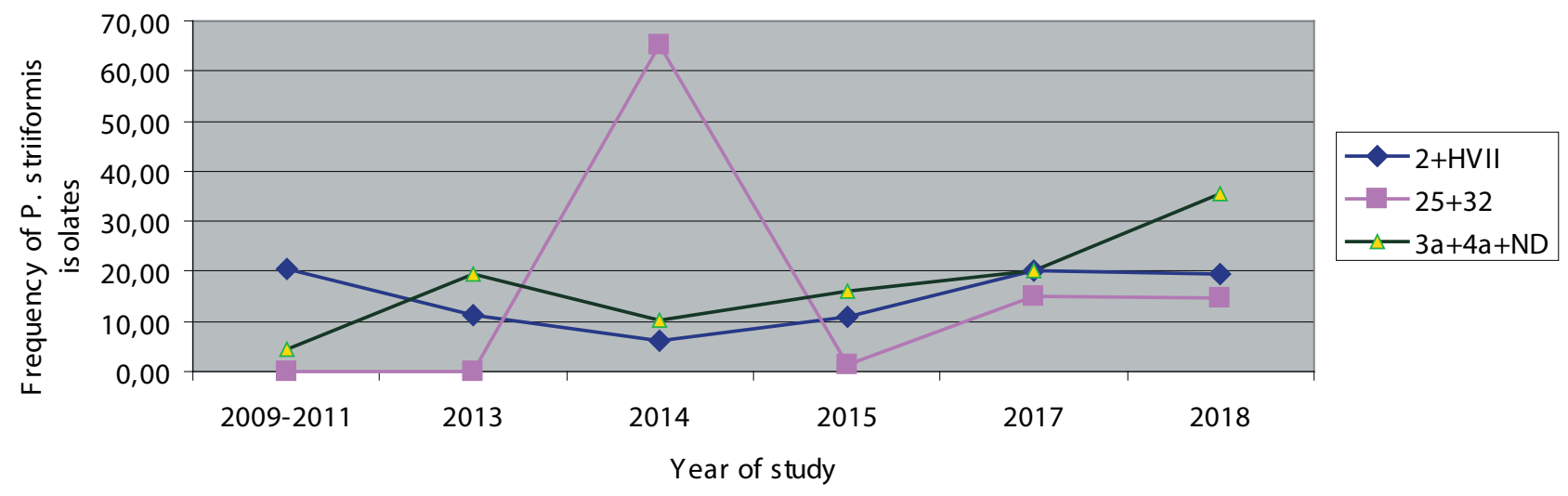

Figure 2. Frequencies of Puccinia striiformis isolates in South Russia from 2009 to 2018 with virulence to the European set of differential wheat varieties. 


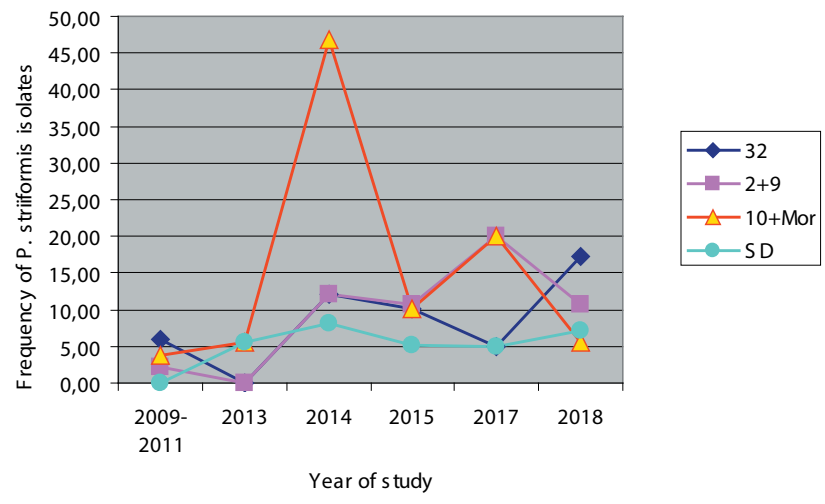

Figure 3. Frequencies of Puccinia striiformis isolates in South Russia during 2009 to 2018, with virulence to the host varieties and lines of the International and Australian differential sets.

and objective analysis of the virulence of the P. striiformis population, differentiation in the southern region of Russia was carried out using the international, American, European and Australian host differential sets.

\section{CONCLUSIONS}

These studies of the P. striiformis populations in South Russia have shown that even in conditions unfavourable for the pathogen, yellow rust of wheat occurred in the region every year, and in some areas there were foci of the disease with of up to $50 \%$ severity. Effective host genes for resistance to P. striiformis were the $Y r$ genes 3, 5, 26, and Sp. At the same time, host lines with genes $\operatorname{Yr} 5$ and $\operatorname{Yr} S p$ have continued to be resistant since 2009. Single (from 1 to 5\%) occurrences of isolates virulent to host lines with several $\mathrm{Yr}$ genes were observed, including gene $3 a, 17,24,3 b+4 a+H 46$, and $3 c+$ Min. According to the Shannon diversity indices, phenotypic composition of the P. striiformis population in South Russia has been established. This confirms is a characteristic feature of the population, as described in previous studies (Shumilov et al., 2015; Volkova et al., 2020). The differences in P. striiformis populations in the frequency of virulence genes between years are insignificant. During the five years of the present study, there were intensive virulence dynamics and changes in the frequency of virulence to host $Y r$ genes in the pathogen population. This feature in South Russia, combined with high phenotypic diversity, indicates the ability of $P$. striiformis for rapid race formation and morphogenesis in response to changes in biotic and abiotic environmental factors. This dictates the need for continued monitoring of an important pathogen in this region. The obtained long-term data on the dynamics of virulence of $P$. striiformis are important for understanding the interaction mechanisms of this host-pathogen system, and provide a necessary link in breeding for resistance to yellow rust in South Russia.

\section{ACKNOWLEDGEMENTS}

Researchers of the Laboratory of Immunity of Cereal Crops to Fungal Diseases of the Federal Scientific Center for Biological Plant Protection assisted in this research. Mrs. A. V. Danilova and Mrs. O. Miroshnichenko helped with collection of yellow rust affected plant material, and Mrs. O. Vaganova, Mrs. Gladkova E. V. gave technical assistance. The research was carried out in accordance with State Assignment No. 075-00376-19-00 of the Ministry of Science and Higher Education of the Russian Federation, within the framework of Topic No. 0686-2019-0008.

\section{LITERATURE CITED}

Afshari F., 2008. Prevalent pathotypes of Puccinia striiformis f. sp. tritici in Iran. Journal of Agricultural Science and Technology 10: 67-78.

Aktar-Uz-Zaman M., Tuhina-Khatun M., Hanafi M.M., Sahebi M., 2017. Genetic analysis of rust resistance genes in global wheat cultivars: an overview. Biotechnology \& Biotechnological Equipment 31(3): 431-445.

Ali S., Rodriguez-Algaba J., Thach T., Sorensen C.K., Hansen ... Hovmoller M.S., 2017. Yellow rust epidemics worldwide were caused by pathogen races from divergent genetic lineages. Frontiers in Plant Science 8: 1057.

Anpilogova L.K., Volkova G.V., 2000. Development Methods of Artificial Infectious Backgrounds and Wheat Varieties Assessment for Resistance to Harmful Diseases (spike fusarium, rust, powdery mildew). Recommendations. Krasnodar: RAAS, ARRIBPP, 28 pp. (in Russian)

Ashmawy M.A., Shahin A.A., Samar M.E., Hend A.N., 2019. Virulence dynamics and diversity of Puccinia striiformis populations in Egypt during 2017/18 and 2018/19 growing seasons. Journal of Plant Protection and Pathology 10 (12): 655-666.

Berdysh Yu. I., 2002. Phytosanitary Monitoring and Scientific Substantiation of Winter Wheat Protection Against Pests on Black Earth Soil of Western Ciscaucasia. PhD Thesis, Krasnodar, Russia, 173 pp. (in Russian) 
Brar G.S., McCallum B.D., Gaudet D.A., Puchalski B.J., Fernandez M.R., Kutcher H.R., 2016. Stripe rust disease dynamics in southern Alberta, Saskatchewan, and Manitoba, 2009-2014. Canadian Journal of Plant Pathology 38: 114-115.

Brar G.S., Dhariwal R., Randhawa H.S., 2018. Resistance evaluation of differentials and commercial wheat cultivars to stripe rust (Puccinia striiformis) infection in hot spot regions of Canada. European Journal of Plant Pathology 152: 269.

Bux H., Ashraf M., Chen X., Mumtaz A.S., 2011. Effective genes for resistance to stripe rust and virulence of Puccinia striiformis f. sp. tritici in Pakistan. African Journal of Biotechnology 10(28): 5489-5495.

Bux H., Rasheed A., Mangrio S.M., Abro S.A., Shah S.J.A., ... Chen X., 2012. Comparative virulence and molecular diversity of stripe rust (Puccinia striiformis f. sp. tritici) collections from Pakistan and United States. International Journal of Agricultural Biology 14: 851-860.

Chen X. M., 2005. Epidemiology and control of stripe rust (Puccinia striiformis $\mathrm{f}$. sp. tritici) on wheat. Canadian Journal of Plant Pathology 27: 314-337.

Chuprina V.P., Sokolov M.S., Anpilogova L.K., Kobileva E.A., Levashova G.I., Pikushova V.V., 1999. Protection of wheat crops against stripe rust, taking into account the epiphytotic and biotrophic characteristics of its pathogen Puccinia striiformis West. Agrochemistry 7: 81-94. (in Russian)

Dobryanskaya M.V., Anpilogova L.K., Vysotskaya N.I., 1999. Model of sporulation of the stripe rust pathogen. Protection and Quarantine of Plants 8: 25-26. (in Russian)

Gerechter-Amitai Z.K., Sifhou C.H., Grama A., Kleitman F., 1989. Yr15: a new gene for resistance to Puccinia striiformis in Triticum dicoccoides sel. G-25. Euphytica 43: $187-190$.

Gebreslasie Z.S., Huang S., Zhan G., Badebo A., Zeng Q.,... Kang Z., 2020. Stripe rust resistance genes in a set of Ethiopian bread wheat cultivars and breeding lines. Euphytica 216(2): 17.

Green G.J., 1965. Stem rust of wheat, rye and barley in Canada in 1964. Plant Disease Survey 45(1): 23-39.

Han D.J., Wang Q.L., Chen X.M., Zeng Q.D., Wu J.H., ... Kang, Z. S., 2015. Emerging Yr26-virulent races of Puccinia striiformis $f$. tritici are threatening wheat production in the Sichuan Basin, China. Plant Disease 99(6): 754-760.

Hovmøller M.S., Justesen A.F., 2007. Rates of evolution of avirulence phenotypes and DNA markers in a northwest European population of Puccinia striiformis $\mathrm{f}$. sp. tritici. Molecular Ecology 16: 4637-4647.
Hovmøller M.S., Rodriguez-Algaba J., Thach, T., Sørensen, C.K., 2017. Race typing of Puccinia striiformis on wheat. In: Wheat rust diseases. Humana Press, New York, NY, USA 29-40.

Hovmøller M.S., Rodriguez-Algaba J., Thach T., Justesen, A.F., Hansen J.G., 2018. Report for Puccinia striiformis race analyses and molecular genotyping 2017. Global Rust Reference Center (GRRC), Aarhus University, Flakkebjerg, DK-4200 Slagelse, Denmark. Available at: https://agro.au.dk/fileadmin/Summary_ of_Puccinia_striiformis_race_analysis_2017.pdf

Hovmøller M.S., Rodriguez-Algaba J., Thach T., Justesen A.F., Hansen J.G., 2020. GRRC annual report 2019: Stem and yellow rust genotyping and race analyses. Aarhus University, Department of Agroecology, DK-4200 Slagese, Denmark. Available at: https://agro. au.dk/fileadmin/www.grcc.au.dk/International_Services/ Pathotype_YR_results/GRRC_annual_report_2019.pdf

Huerta-Espino J., Singh R.P., 2017. First detection of virulence in Puccinia striiformis $\mathrm{f}$. sp. tritici to wheat resistance genes Yr10 and Yr24 (= Yr26) in Mexico. Plant Disease 101(9): 1676-1676.

Kolmer J.A., Long D.L., Kosman, E., Hughes, M.E., 2003. Physiologic specialization of Puccinia triticina on wheat in the United States in 2001. Plant Disease 87: 859-866.

Kosman E., 1996. Difference and diversity of plant pathogen populations: a new approach for measuring. Phytopathology 86: 1152-1155.

Kosman E., Leonard K.J., 2007. Conceptual analysis of methods applied to assessment of diversity within and distance between populations with asexual or mixed mode of reproduction. New Phytologist 174: 683-696.

Kumar K., Holtz M.D., Xi K., Turkington T.K., 2012. Virulence of Puccinia striformis on wheat and barley in central Alberta. Canadian Journal of Plant Pathology 34(4): 551-561.

Line R.F., 2002. Stripe rust of wheat and barley in North America: A retrospective historical review. Annual Review of Phytopathology 40: 75-118.

Liu T., Wan A., Liu D., Chen X., 2017. Changes of races and virulence genes in Puccinia striiformis f. sp. tritici, the wheat stripe rust pathogen, in the United States from 1968 to 2009. Plant Disease 101(8): 15221532.

MacKenzie D., 2011. Crop disease to add to east Africa's woes [Electronic resource]. 1 p. Available at: http:// www.newscientist.com/article/mg21128214.100-cropdisease-to-add-to-east-africas-woes.html

Matveeva I.P., Volkova G.V. 2019. Wheat yellow rust: Distribution, harmfulness, control measures (review). 
Bulletin of the Ulyanovsk State Agricultural Academy 2 (46):102-116. (in Russian)

McIntosh R.A. Lagudah E.S., 2000. Cytogenetical studies in wheat. XVIII. Gene Yr24 for resistance to stripe rust. Plant Breeding 119: 81-83.

Morozova A.A., 1974. Species composition of winter wheat rust and their distribution in the Krasnodar Territory. Proceedings of the Kuban Agricultural Institute 79 (107): 49-55. (in Russian)

Rahmatov M., 2016. Genetic Characterisation of Novel Resistance Alleles to Stem Rust and Stripe Rust in Wheat-Alien Introgression Lines. PhD Thesis, Alnarp, Swedish University of Agricultural Sciences, Sweden, 76 pp.

Roelfs A.P., Singh R.P., Saari E.E., 1992. Rust Diseases of Wheat: Concepts and Methods Management. CIMMIT, Mexico, $81 \mathrm{pp}$.

Rsaliev Sh.S., 2008. A new method for differentiating wheat yellow rust. Science News of Kazakhstan 2: 143-146. (in Russian)

Sanin S.S., Nazarova L.N., 2010. Phytosanitary situation on wheat crops in the Russian Federation (1991-2008). Protection and Quarantine of Plants 2: 20 p. (in Russian)

Shahin A., Ashmawy M., El-Orabey W., Esmail S., 2020. Yield Losses in Wheat Caused by Stripe Rust (Puccinia striiformis) in Egypt. American Journal of Life Sciences 8 (5): 127-134.

Shumilov Yu.V., 2013. Agrobiological Substantiation of Methods of Reducing the Infectious Potential of the Wheat Stripe Rust Pathogen in the North Caucasus. $\mathrm{PhD}$ Thesis, N.I. Vavilov Saratov State Agricultural University, Russia, 24 pp. (in Russian)

Shumilov Yu.V., Volkova G.V., 2013. Wheat stripe rust requires special attention. Protection and Quarantine of Plants 8: 13-14. (in Russian)

Shumilov Yu.V., Volkova G.V., Nadykta V.D., 2015. Structure of the wheat stripe rust pathogen population by virulence in the North Caucasus. Mycology and Phytopathology 49(3): 194-200. (in Russian)

Singh R.P., William H.M., Huerta-Espino J., Rosewarne G., 2004. Wheat Rust in Asia: Meeting the challenges with old and new technologies. In: New directions for a diverse planet. Proceed. 4th International Crop Science Congress, September 26 to October1, Brisbane, Australia. Available at: http://www.cropscience.org. au./icsc2004/symposia/3/7/141_singhrp.html

Smirnova L.A., Alekseeva T.P., 1988. An improved method of cultivation of seedlings of grain crops for immunological studies. Selection and Seed Production 4: 25-27. (in Russian)

Volkova G.V., Shulyakovskaya L.N., Kudinova O.A., Matveeva I.P., 2018. Wheat yellow rust in the Kuban. Plant Protection and Quarantine 4: 29. (in Russian)
Volkova G.V., Matveeva I.P., Kudinova O.A. 2020. Virulence of the wheat yellow rust pathogen population in the North Caucasus region of Russia. Mycology and Phytopathology 54(1): 33-41. (in Russian)

Waqar A., Khattak S.H., Begum S., Rehman T., Rabia A. ... Ali. G.M., 2018. Stripe rust: A review of the disease, Yr genes and its molecular markers. Sarhad Journal of Agriculture 34(1): 188-201.

Wan A.M., Chen X.M., 2014. Virulence characterization of Puccinia striiformis f. sp. tritici using a new set of Yr single-gene line differentials in the United States in 2010. Plant Disease 98: 1534-1542.

Wang M., Chen X., 2017. Stripe rust resistance. In: Stripe Rust (Chen X., Kang Z. ed.), Springer, Dordrecht, 353-558.

Wellings C.R., McIntosh R.A., 1990. Puccinia striiformis f. sp. tritici in Australasia: pathogenic changes during the first 10 years. Plant Pathology 39 (2): 316-325.

Wellings C.R., Kandel K.R., 2004. Pathogen dynamics associated with historic stripe (yellow) rust epidemics in Australia in 2002 and 2003. In: Proceedings of the 11th International Cereal Rusts and Powdery Mildews Conference. Abstr. A2.74.1 p. Available at: http:// www.crpmb.org/icrpmc11/abstracts.html

Wellings C.R., 2011. Global status of stripe rust: a review of historical and current threats. Euphytica 179: 129141. 